\title{
Reviewing Some Properties of Ultra High Performance Concrete
}

\author{
Shweta Mishra, Renisha Mistry \\ Parul University
}

\begin{abstract}
This paper, a comprehensive literature review has been conducted to highlight the manufacturing principles and properties of UHPC. The affluent production of UHPC depends upon its compositional materials, water to binder ratio and the mix design approach. This review also divulges that the curing conditions, aggregates and fibre properties, specimen size and the strain rates are the key factors in controlling the mechanical and durability properties of UHPC. Moreover, along with its various properties, attempts have been made to address the current challenges and their solutions so far, for their widespread economical usage.
\end{abstract}

Keywords: Design approach, Durability properties, Interfacial transition zone, Manufacturing principles, Mechanical properties, Ultra high performance concrete.

\section{INTRODUCTION}

The newfangled UHPC is basically a special type of concrete having a minimum compressive and tensile strengths of $150 \mathrm{MPa}$ and $8 \mathrm{MPa}$ respectively, while fulfilling the specified criteria of better ductility, durability and toughness requirements along with far better permeability resistance to chemicals as compared to ordinary concretes [5]. Moreover, it gives far better results than conventional concrete under blast, impact and seismic loadings [6]. In spite of all these advantages, it has some drawbacks also. The production of UHPC requires very high amount of binder content (approx. $800-1000 \mathrm{~kg} / \mathrm{m}^{3}$ ) which affects its heat of hydration along with its production cost [7]. It's complicated mix design and very high manufacturing cost has limited its use to the mass structures only. Hence, studies are required to overcome these drawbacks and to make it an economical and efficient construction material.

\section{MANUFACTURING PRINCIPLE}

The most important principle for the production of UHPC includes i) microstructure improvement ii) homogeneity enhancement iii) porosity reduction iv) excellent hydration and $\mathrm{v}$ ) toughness betterment [8]. In comparison to conventional concrete, its Interfacial Transition Zone(ITZ) is extremely dense, less porous and highly compact (Fig. $3)$. It is due to the use of low water-cement ratio and pozzolanic chemical reactions between $\mathrm{CH}$ and reactive admixtures, because of which maximum $\mathrm{CH}$ crystals get converted into dense CSH gel [11]. Hence, UHPC is characterized by an advance microstructure due to its solid particle's close packing and improved ITZ. Enhancement in homogeneity is the second principle required for the production of UHPC. As the size of these cracks is directly proportional to the aggregate's size, reducing aggregate's size in UHPC will effectively reduce the crack size as well as it also makes the ITZ to look similar to the cement paste matrix.

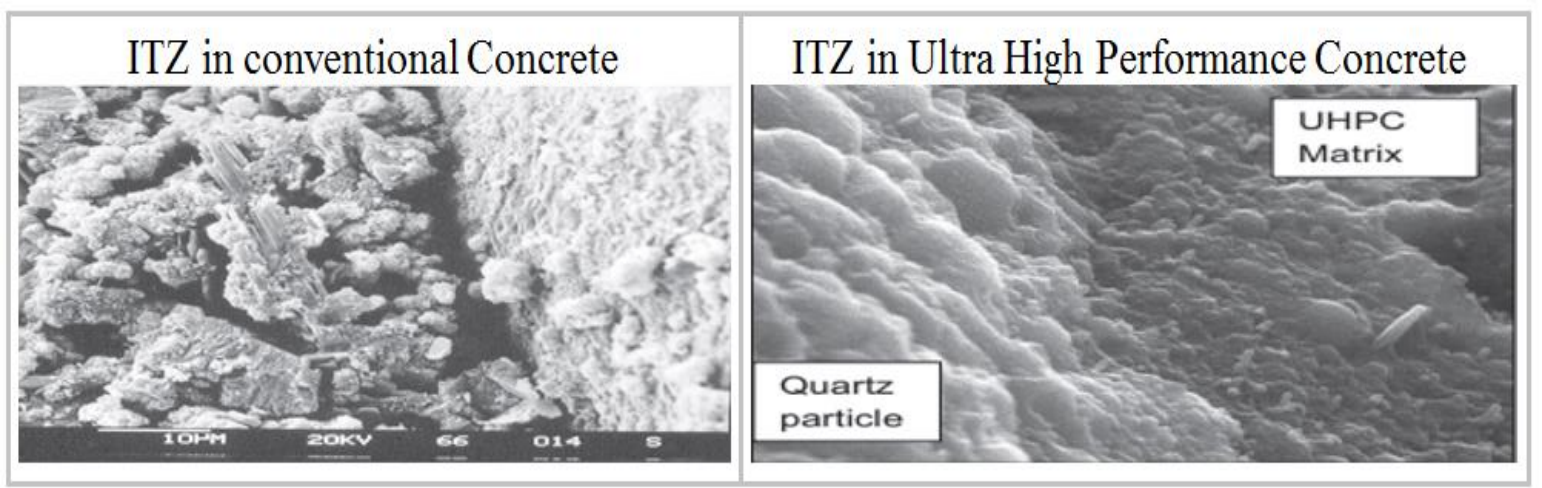

Fig. 3. ITZ in conventional concrete vs UHPC $[11,148]$

The third important principle is the porosity reduction. The porosity of concrete can be reduced by reducing its watercement ratio while latter can be reduced by using superplasticizers, introducing very fine admixtures or packing the raw materials very closely, hence providing higher strength to the matrix $[14,15]$.

According to fourth principle, first the hydration of portland cement will take place to produce $\mathrm{CH}$ and $\mathrm{CSH}$ gel, after which produced $\mathrm{CH}$ will react further with fine admixtures (silica fume etc.) to form $\mathrm{CSH}$ gel again. It has been found that UHPC have lesser amorphous phases as compared to higher crystalline phases in conventional concrete due to pozzolanic reactions with highly fined mineral admixtures [16].

The last principle states that UHPC should have high toughness i.e. the material capacity to absorb energy should 
be high enough to withstand its fracture. Fibres are introduced in them to prevent as well as control the initiation and propagation of cracks. Zollo [19] states that the concrete matrix bears the load directly and transfer it to the fibres whereas the fibres control the growth of the cracks generated by using their better energy absorption capacity.

High quality cement with cementitious additives (mainly silica fume), aggregates, and large quantity of superplasticizers along with fibre addition are the main compositional materials of UHPC (Fig. 4). As the UHPC matrix is much denser than conventional concrete, all granular constituents should have the maximum packing density. To increase the packing density of concrete matrix, one should increase the different size classes of binder as well as that of aggregates so that the voids in between the larger particles can be filled by the smaller ones [10]. The incorporation of this well graded system will also help to improve the workability of the fresh concrete to some extent by introducing ball bearing effect between the finer and coarser particles and reducing the requirement of cement paste for lubricating the particle's surface. But it has been noticed that a completely dense packing is not befitting as the fresh concrete needs to flow to certain degree before it gets placed [21].Hence, addition of waterreducing agents in the mix will counteract the effect of low water-binder ratio and fibre's addition to maintain minimum required workability[10,21].

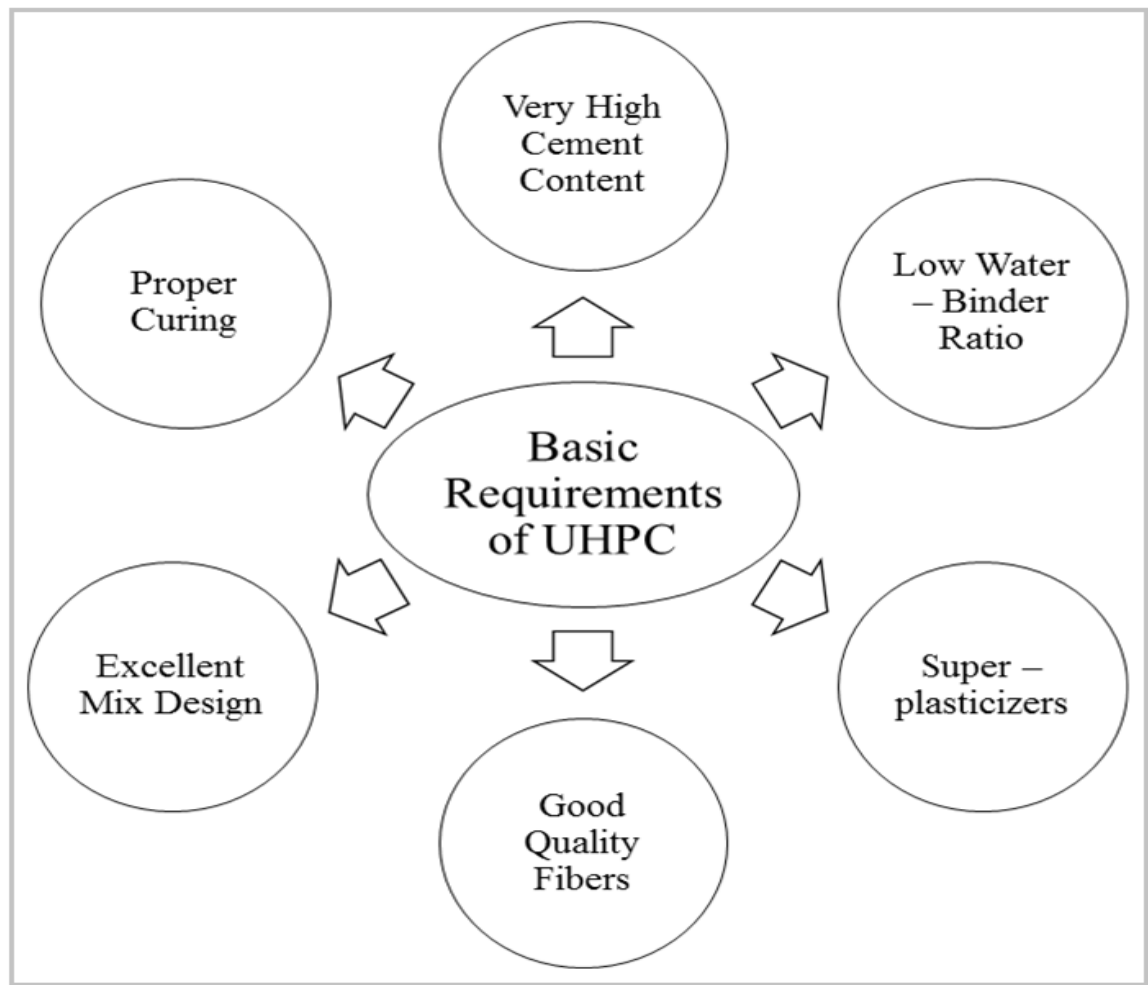

Fig. 4. Basic requirements of UHPC [OM]

Generally, cement content required for the production of UHPC $\left(600-1000 \mathrm{~kg} / \mathrm{m}^{3}\right)$ is approximately twice the amount of cement required in ordinary concrete [21]. As all the cement particles do not react due to low water-cement ratio, left over unhydrated cement behaves inertly and will be used in particle packing [21]. Other materials having cementitious properties like Silica Fume (SF), Fly Ash(FA), metakaoline etc. can be used as a replacement (partially or completely) for cement. Silica fume particles are very small as compared to cement particles which makes them an excellent filler material increasing the packing density of the matrix [20,23]. Fly ash particles are mainly spherical in shape having ball bearing effect which helps to enhance the flowability of fresh concrete, increasing the setting time, decreasing the permeability and reducing sulphate attacks on cement replacement with it [24]. Using metakaolin as a cement replacement will reduce autogenous shrinkage, increases flexural strength but with a small decrease in the compressive strength [25].
Rice Husk Ash (RHA), Ground Granulated Blast Furnace Slag (GGBFS) and nano-particles are some other cement replacement materials which can play an indispensable role in improving the properties of UHPC. Sobolevand Gutiérrez [28] showed that nano-particles (nano-silica, nano-iron, nano- $\mathrm{CaCO}_{3}$, etc.) have the highest surface areavolume ratio as compared to other cementitious materials (Fig. 5).They have the ability to densify the microstructure by acting as a filler material as well as promoting further cement hydration because of their high reactivity by acting as cement phase nucleus [29].With the use of these nanomaterials in UHPC, compressive and flexural strength increases significantly. Being very small in size, nanosilica make the matrix very dense by filling the voids in between SF and cement particles. This will definitely escalate the mechanical as well as durability properties of UHPC [30,31,32]. Matrix having nano-silica and have higher bonding strength between aggregates and binder paste than matrix containing SF or cement only [21]. 


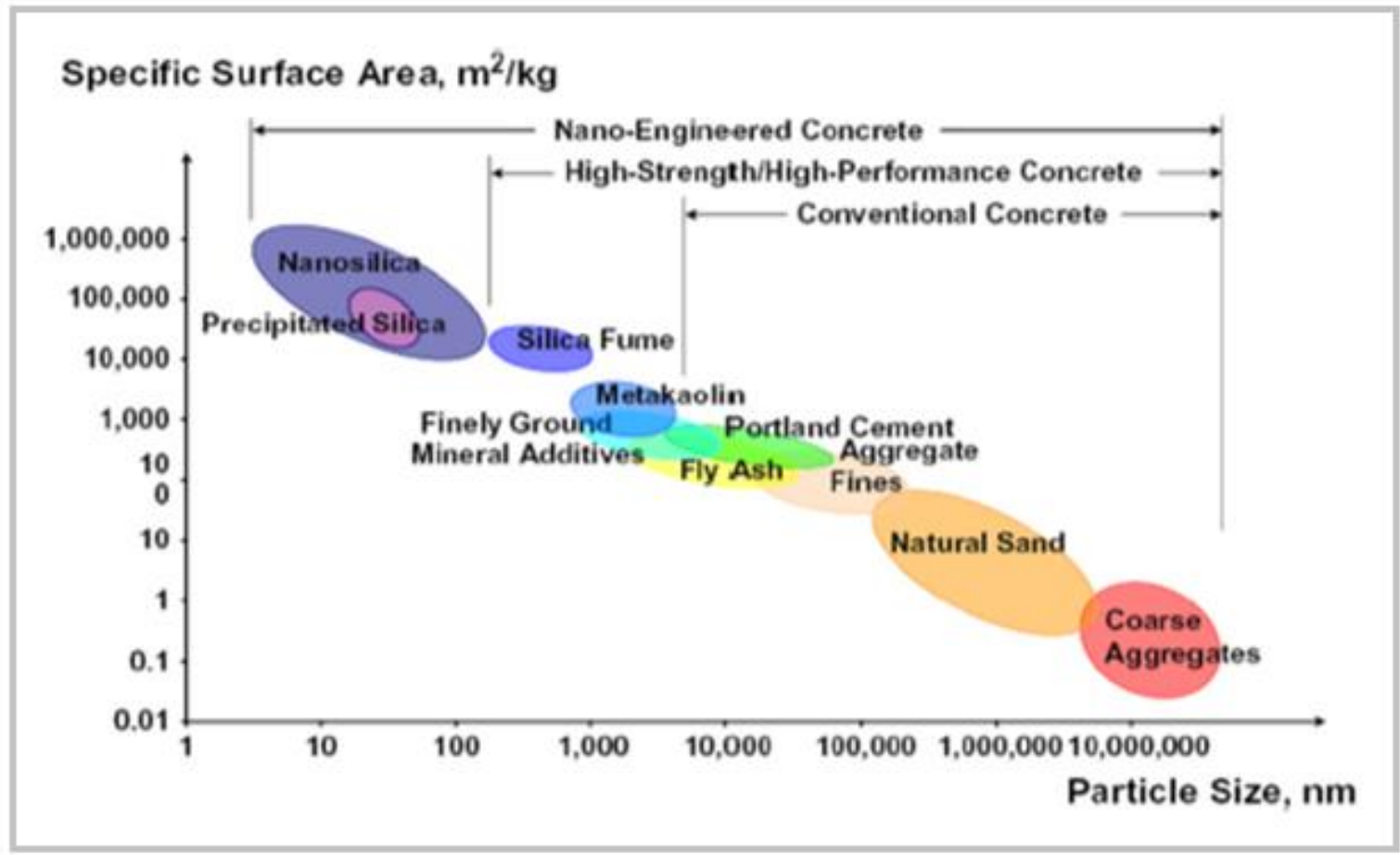

Fig. 5. Comparison between various concrete materials [28]

Normally, aggregate is considered to be an inert material but it plays a very crucial role in deciding the dimensional stability of the concrete along with its elastic and thermal properties. The best aggregates which should be used for UHPC are characterized by high mechanical strength (hard, durable etc.), well graded size distribution and free from any harmful contaminants (clay, silt, chemicals etc.) so that it may not affect the hydration process, strength, density and porousness of the concrete matrix. Incorporation of these materials as fine aggregates in the concrete composite will enhance packing density, increases strength and add durability. The important point which should be kept in mind while selecting the aggregates for UHPC is that they should not have susceptibility for breaking and should have higher resistance to weathering. Moreover, they should have high mechanical strength and should be characterized with well graded size distribution, appropriate shape and texture. Generally, apart from fine aggregates, coarse aggregates are rarely used in the production of UHPC from strength point of view. But, addition of coarse aggregates in the concrete mix have the ability to reduce autogenous shrinkage, cement quantity and hence the cost of UHPC [38]. Hence, proper size of coarse aggregates which can satisfy both strength as well as cost, can be used as a construction material.

According to the principle of production, UHPC requires a very high binder content at a very low water-cement ratio of 0.14 to 0.20 [8]. Hence, addition of superplasticizers like polycarboxylate are very much required to provide the required workability to the concrete mix [39].The amount and type of superplasticizer to be employed, should be chosen on the basis of the quality of UHPC to be obtained. The optimum content required for obtaining best mechanical and durability properties, as concluded from various research works in the past decade is 1.50 to 2.40 [OM].

\section{FACTORS AFFECTING PROPERTIES}

The binder materials i.e., cementitious and Supplementary Cementitious Materials (SCMs) have a dominant role in deciding the ultimate characteristics of any concrete. Due to fast reactivity of $\mathrm{C}_{3} \mathrm{~S}$ with water, the cement having high content of $\mathrm{C}_{3} \mathrm{~S}$ and lower content of $\mathrm{C}_{2} \mathrm{~S}$ will show early development of strength whereas the one having higher percentage of $\mathrm{C}_{2} \mathrm{~S}$ and lower percentage of $\mathrm{C}_{3} \mathrm{~S}$ and $\mathrm{C}_{3} \mathrm{~A}$ will produce a concrete with low heat of hydration, slower rate of strength development and better resistance to sulphate attack [78].Hence, the properties of UHPC can easily be modified as per the need by just changing the composition of these cementitious materials. In addition to this, various types of SCMs like FA, GGBFS, SF, RHA etc. also have some discernible effects on the quality of UHPC as per their own physical and chemical traits. Incorporation of some SCMs like FA, RHA, MK will enhance the workability of UHPC by reducing the water demand whereas other SCMs like SF, nano-materials, zeolites increases the water demand and decreases workability either due to their high reactivity, ultrafine particles or water absorption tendency [78,79].Generally, most of the SCMs in spite of their type contributes better mechanical strength, greater sulphate resistance and enhanced impermeability against gas and chemical attacks $[77,78,79,80,81,82,83]$. This is mainly due to their filling effect, pozzolanic reaction converting $\mathrm{CH}$ into $\mathrm{CSH}$ and the refinement of concrete's microstructure simultaneously. According to Mehta and Monteiro [84],aggregate's shape, size, texture, gradation, specific gravity, soundness and moisture content are some of the key factors which plays an important role while obtaining a desirable concrete 
(Table 6) $[\mathrm{OM}]$. Aggregates are mainly classified into coarse and fine aggregates. In UHPC, fine aggregates are preferred as they provide better mechanical strength and workability. But they increase the cost of manufacturing.
Hence, using some percentage of coarse aggregates can significantly reduce the cost but will affect the strength parameter also.

Table 6: Effect of various properties of aggregates

\begin{tabular}{|c|c|c|}
\hline Parameters & Type & Important Notes \\
\hline \multirow{2}{*}{ Shape } & Rounded & $\begin{array}{ll}> & \text { Void percent }=32-33 \% . \\
> & \text { Less cement required. } \\
> & \text { More workable while poor strength. }\end{array}$ \\
\hline & Angular \& Elongated & $\begin{array}{ll} & \text { Void percent }=38-40 \% \\
> & \text { More cement required. } \\
> & \text { Less workable while good strength } \\
\end{array}$ \\
\hline \multirow[b]{2}{*}{ Texture } & Smooth & $>$ It improves workability but have lower strength \\
\hline & Rough & $\begin{array}{l}\text { It improves paste-aggregate bond strength but lower } \\
\text { workability }\end{array}$ \\
\hline \multirow{2}{*}{$\begin{array}{l}\text { Gradation } \\
\text { Or } \\
\text { Size Distribution }\end{array}$} & Uniform Graded & $\begin{array}{ll}> & \text { Max. Particle's spacing. } \\
> & \text { High binder paste requirement. } \\
> & \text { Provides good workability while lower strength. } \\
\end{array}$ \\
\hline & Well Graded & $\begin{array}{ll}> & \text { Min. Particle's spacing. } \\
> & \text { Less binder paste required. } \\
> & \text { Provides good strength while lower workability. }\end{array}$ \\
\hline \multirow{2}{*}{ Moisture Content } & Wet Dry & $\begin{array}{l}> \\
>\quad \text { Up to } 5 \% \text { water absorption. } \\
\quad \text { Can cause bulking. }\end{array}$ \\
\hline & Air Dry & $\begin{array}{l} \\
\quad \text { Less than } 1 \% \text { water absorption. } \\
\text { No problems of bulking }\end{array}$ \\
\hline \multirow{2}{*}{ Density } & Light weight & $>\quad<1100 \mathrm{~kg} / \mathrm{m}^{3}$. \\
\hline & Normal weight & D $\quad 1500-1700 \mathrm{~kg} / \mathrm{m}^{3}$. \\
\hline
\end{tabular}

Packing density is an important factor which plays a key role in deciding the performance and major properties of UHPC. The packing density can easily be increased by improving the size distribution, shape and texture of cementitious materials and aggregates [87]. This enhancement in packing density will led to the improvement in flowability and workability of fresh UHPC due to the reduction in water demand and greater availability of binder paste for carrying out lubrication. Moreover, the improvement in the packing of constitute ingredients and reduced water-binder ratio will lead to the strength increment and reduction in porosity, bleeding, segregation, permeability and shrinkage of UHPC $[87,88,89]$.

Fibres i) geometry and type, ii) length, iii) volume content with dispersion homogeneity, and iv) orientation are some of the important factors which significantly affect the properties of UHPC. It has been found that the deformed fibres (twisted - TF, hooked end - HF, triangular, polygonal, square shapes etc.) are much better than straight fibres (SF) in terms of strength and post-cracking strain [90]. It is mainly because of better interfacial bond properties of hybrid fibres with the UHPC matrix resulting in three to four times greater pull-out bond strength and toughness in respect to straight and corrugated fibres. The ultra high performance concrete (UHPC) with deformed fibre reinforcement provided an increment of $32 \%, 70 \%$, and $205 \%$ in tensile strength, flexural strength and strain capacity respectively, but only insignificant improvements were observed in terms of compressive strength and elastic modulus as compared to SF reinforcement [90,91]. In comparison to straight fibres, Wu et al. [92] have also observed somewhat similar increment of $17 \%-50 \%$ and $8 \%-28 \%$ in the ultimate flexural strength of UHPC on incorporation of hybrid and corrugated fibres respectively. Now, the bonding area between the matrix and its fibres along with the fibres probability to be present at the surface of cracks increases with increase in the fibre's length [93]. Due to this, flexural strength and toughness of the matrix gets enhanced along with its load carrying capacity on incorporating longer fibres. UHPC mix having $2.0 \%$ long fibre incorporation have shown better static compressive and flexural strength in comparison to $2.0 \%$ sort fibre reinforcement [94]. But, UHPC having hybrid long and short fibre reinforcement will have better results in terms of flowability and strength when compared to single long or short fibre reinforcement. Wu et al. [94,95] have obtained the best results in terms of static and dynamic mechanical strength for hybrid $1.5 \%$ long- $0.5 \%$ short fibres in comparison to $2.0 \%$ long or short fibre reinforcement. The major reason behind this efficiency is the collaboration of short and long fibres which makes them capable of withstanding the widening of micro as well as macro cracks and bearing the applying load up to larger deflection, hence showing better mechanical strength, ductility and toughness. 


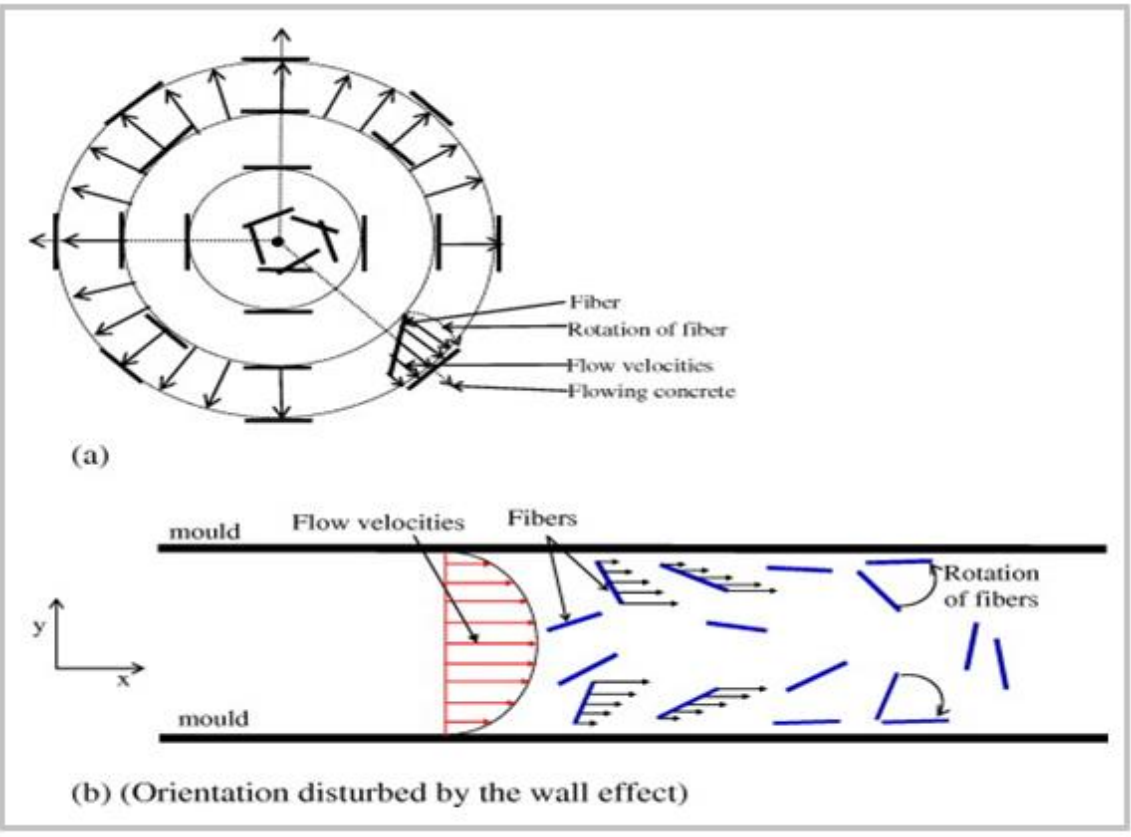

Fig. 9. Fibre orientation a) radial flow b) shear flow [97]

Mainly, increasing the volume of fibres up to the optimum value will improve the compressive strength, tensile strength and flexural strength of UHPC drastically. But this strength improvement also depends upon the homogeneity of dispersion of fibres in the concrete mix [96].Generally, researchers have suggested a fibre content of $1 \%$ to $4 \%$ for getting the best strength properties. But, the volume of fibre used in the matrix should be minimum from the economical point of view since even the cost of $1 \%$ volume of fibre can be greater than the whole matrix material. Hence, fibre volume in between $1 \%$ to $2 \%$ is more than sufficient for obtaining required structural performance economically. In good fibre orientation, maximum fibres are well and homogeneously aligned in the direction of tensile load, whereas in poor fibre orientation, maximum fibres are randomly oriented and not homogeneously aligned in the direction of tensile load. There are mainly two types of flows i.e. shear flow and radial flow in which fibres get aligned either perpendicularly or parallel to the fluid flow direction, respectively as shown in Figure. 9 [97]. Ferrara et al. [98] and Kwon et al. [99] had reported in their result that the beams in which fibres get aligned parallel to the beam length had shown better flexural strength than the beams having fibres orientation perpendicular to their length. This implies that higher flexural and tensile strength along with better energy absorption capacity for UHPC can be achieved from good orientation of fibres in the concrete matrix.

The structures to be made with UHPC are highly bigger than the reduced scale specimens on which we conduct all the tests to check its suitability for the construction work. Hence, various investigations have been made in the past several years to analyse the size effect on various properties of concrete. An et al. [100] had reported that there is a decrement in the compressive strength with an increase in the size of specimen and this effect becomes more noticeable with the increase of fibres dosage. Shear strength and flexural strength also varies inversely proportional to the size of specimen and decreases with the increase in its size [101]. It is generally because the probability of having dense and homogenous microstructure decreases whereas having bigger cracks and voids increases with the increment in sample's size. But, this size effect on the flexural strength of the specimen is mainly due to poor fibre orientation as the later becomes poor with increase in specimen size [102].Hence, specimen size will have a very insignificant effect if similar fibre distribution characteristic along with dense and homogenous microstructure is ensured throughout the specimen and can be easily neglected.

Water-Binder ratio is also a dominant factor in governing the fresh and hardened properties of UHPC. As already discussed in section 3.3, the UHPC mix design requires very low water-binder ratio of $0.18-0.22$ in comparison to conventional concrete. Actually, this water-binder ratio (or water-cement ratio) represents the average distance between the binder's particles within the binder/cement paste just before their hydration starts on addition of water [103]. Hence, lower is the water-binder ratio, lower will be the distance between the adjacent binder particles which means that the hydrates of one particle will need to grow smaller distance in order to meet the hydrates of neighbouring particles. This will increase the packing density, improves the hydration condition and densify the microstructure of UHPC, which will consequently enhance its mechanical strength and durability properties [104].

Strain rate may be defined as the rate of change of a particle's distance with time in respect to its neighbour particle. Lower strain rate allows more creep to occur and greater critical crack growth, resulting in the formation of larger flaws. Concrete's sensitivity towards strain rate also depends upon the loading condition i.e. maximum under tension, minimum under compression while medium under 
flexure [112]. When the strain rate increases during compression loading, it has been seen that the ultimate strain and strain capacity along with compressive strength also increases significantly [113]. Also, the strain rate increases with an increase in the tensile loading which further increases the ultimate tensile strength, toughness and the post cracking tensile strength [114].

It has been found that UHPC show very high tensile resistance at high strain rate in comparison to the static rate [115]. Under dynamic loading, with the increase in the strain rate, the flexural strength and energy were obtained higher than static loading.

\section{MECHANICAL PROPERTIES}

Ultra high performance concrete have a very high compressive strength of $150 \mathrm{MPa}$ or much more as compared to the ordinary concrete. It is to be consider that the UHPC with or without fibres have a very different behaviour under the compressive loading (Fig. 10) [OM]. Fibres do not have much significant role in the improvement of compressive strength but provides a ductile nature to the concrete because of their restraining and confining effect [144]. Later in 2006, Graybeal [145] investigated the curing condition's effect and concluded that the compressive strength increases significantly under steam curing. Compressive strength can also be enhanced due to addition of some fine waste materials in the mix design. Copper Slag (CS) being a waste material can produce an UHPC with a compressive strength of $150 \mathrm{MPa}$ in 28 days of curing [122]. But, if CS completely replaces the standard sand in UHPC, there will be a decrease of about $15-25 \%$ in its compressive strength due to high amount of free water present in case of CS mix [122]. Also, $5 \% \mathrm{SF}$ can produce a compressive strength of $155 \mathrm{MPa}$ at 90 days while using as a binder material. However, silica fume $(>10 \%)$ does not shows any significant changes in the compressive strength, giving strength similar to $5 \% \mathrm{SF}$ addition [132]. Alsalman et al. [132] further concluded that the compressive strength increases by $4 \%$ to $8 \%$ depending upon the specimen size due to addition of $3 \%$ steel fibres. Cube specimens show greater compressive strength (11\%) as compared to cylindrical ones. Other industrial byproducts showing promising results in strength development are FA and Coal Bottom Ash (CBA). Coal bottom ash (CBA) can provide additional compressive strength at 28 days due to its pozzolanic reaction and its highly amorphous structure [134]. Soliman and Hamou [146] has used glass powder for making an eco-friendly UHPC and provided $20 \%$ and $50 \%$ glass powder as the optimum replacement of cement with respect to compressive strength and flowability respectively. A compressive strength of $234 \mathrm{MPa}$ can be attained by complete $100 \%$ replacement of quartz powder with glass powder under hot curing. Infect, complete replacement provides better compressive strength along with cost reduction [146].
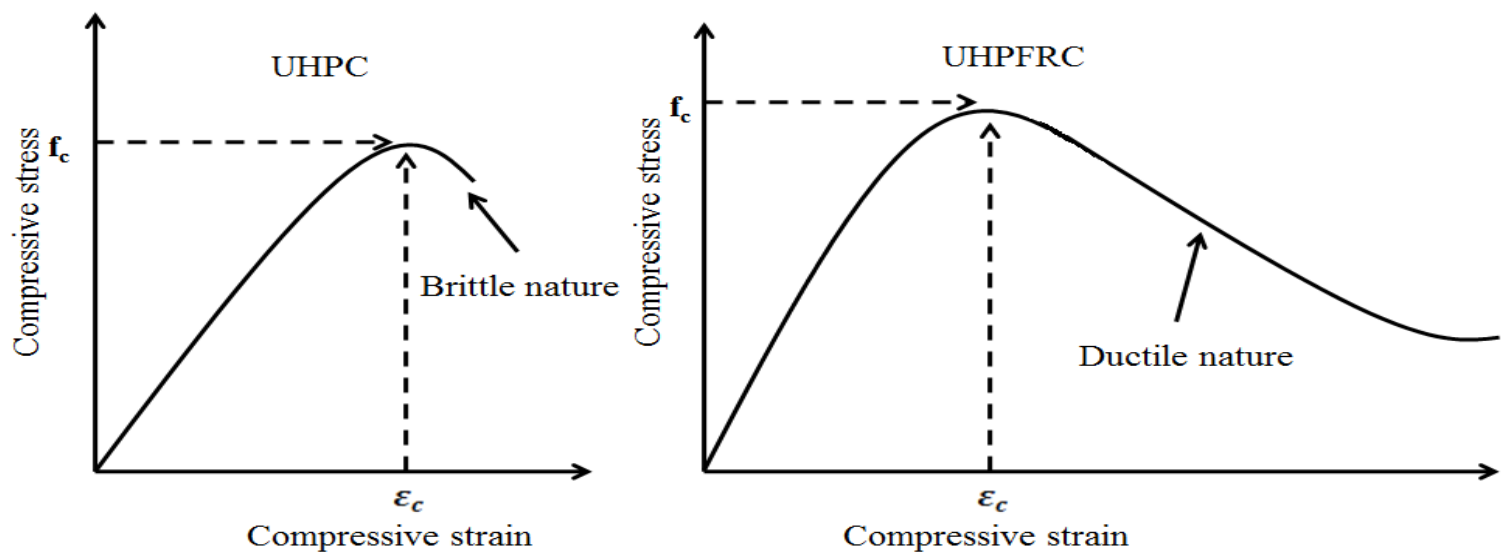

Fig. 10. Compressive stress-strain curve for UHPC and UHPFRC [OM]

Ultra high performance concrete (UHPC) matrix with fibres addition, generally have a tensile strength in the range of $15 \mathrm{MPa}$ to $20 \mathrm{MPa}$ depending upon the matrix property. It is generally twice as that of UHPC without fibres. Ultimate cracking strength (post), energy absorption capacity and the strain capacity are very important tensile parameters which should be properly investigated to observe the tensile behaviour. The strain hardening and strain softening are the two different behaviours which the tensile stress-strain curve shows under multiple and single cracking respectively (Fig. 11) [OM]. Nguyen et al. [147] inspected the effect of geometry and size on the tensile properties of UHPC. The results confirm that the ultimate cracking strength, energy absorption capacity and the strain capacity get reduced on increasing the volume, gauge length and the section area of specimen. Thickness of specimen have an opposite impact because on increasing the thickness, all the parameters get increased significantly. Further, Park et al. [118] have concluded in their research that instead of micro fibre, macro fibres mainly affects the shape of stress strain curve of UHPC under tension. It is noticeable that the tensile properties of UHPC get significantly improved according to the types of fibre used in the matrix. Park et al. [118] compared the effect of different percentage of Long Smooth (LS), Hooked Fibres - Type A, B (HA \& HB) and Twisted Macro Steel (TMS) fibres used with a particular content of micro fibres. Twisted fibres have shown the best results for post cracking strength as well as the strain capacity, followed by the hybrid and smooth fibres. Meng and khayat [126] has 
used Graphite Nano Platelets (GNP) and Carbon Nano Fibres (CNF) to produced UHPC. Results showed that the tensile strength effectively increases (by $56 \%$ \& 45\%) due to incorporation of these nano materials (CNF \& GNP respectively). Moreover, hybridization of fibres can also be introduced in the production of UHPC for better strength and performance. Results demonstrates that Steel (S) and polyethylene (PE) hybrid fibre UHPC (S1-PE0.5) gives better first cracking and ultimate tensile strength as compared to single steel fibre UHPC [125]. Hence, it can be concluded that a combination of high strength synthetic fibres and steel fibres can be used for better tensile property.

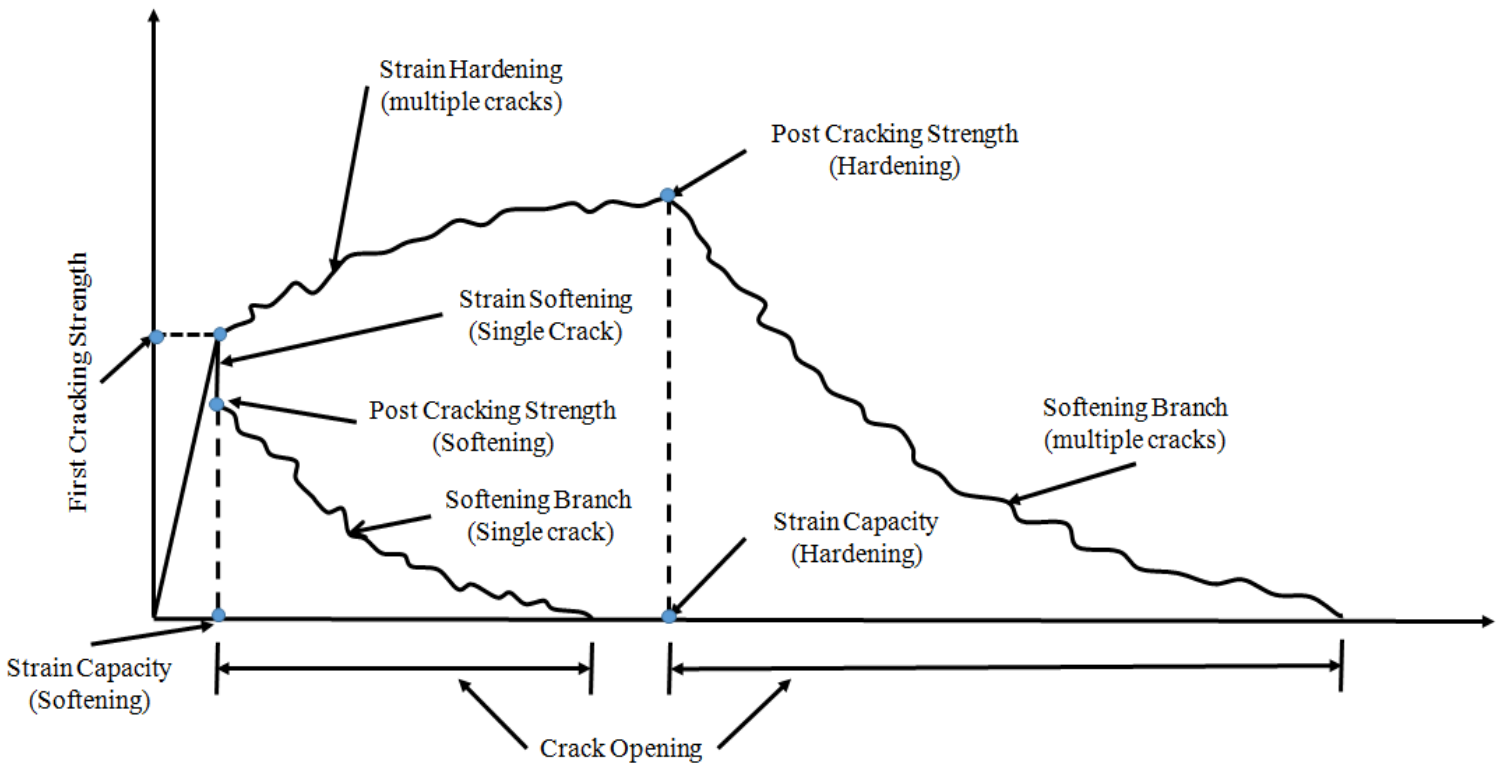

Fig. 11. Tensile stress-strain curve for UHPFRC [OM]

The capacity of a material to resist the structural failure or yield in shear is called the shear strength of that material. UHPC are much better in shear resistance as compared to Normal Strength or High Strength Concrete (NSC/HSC). Hussein and Amleh [123] concluded in their study of UHPC's structural behaviour that the ultimate shear strength of UHPC was higher than NSC/HSC. Generally, UHPC show a very complex behaviour under shear loading. The main factors behind the shear failure of a structure are shearing forces along with bending moments. The resistance to these shear failures is directly proportional to the volume of fibres incorporated in the mix, whereas inversely proportional to the ratio of shear span to depth [133]. There is a huge decrement of about $67 \%$ in the shear strength of UHPC having $1.5 \%$ fibre incorporation due to increase of 0.7 in the shear span to depth ratio. According to Ngo et al. [133], the shear stressstrain curve before the point of first shear cracking shows a linear change whereas a non-linear response up to ultimate shear strength has been observed afterwards (Fig. 12) $[\mathrm{OM}]$. However, a ductile nature has been observed due to the addition of fibres. The experimental results also demonstrated that the shear strength of UHPC was always greater than its tensile strength. The shear strength of $1.5 \%$ fibre mixed UHPC was found approx. 1.6 times greater than its tensile strength.

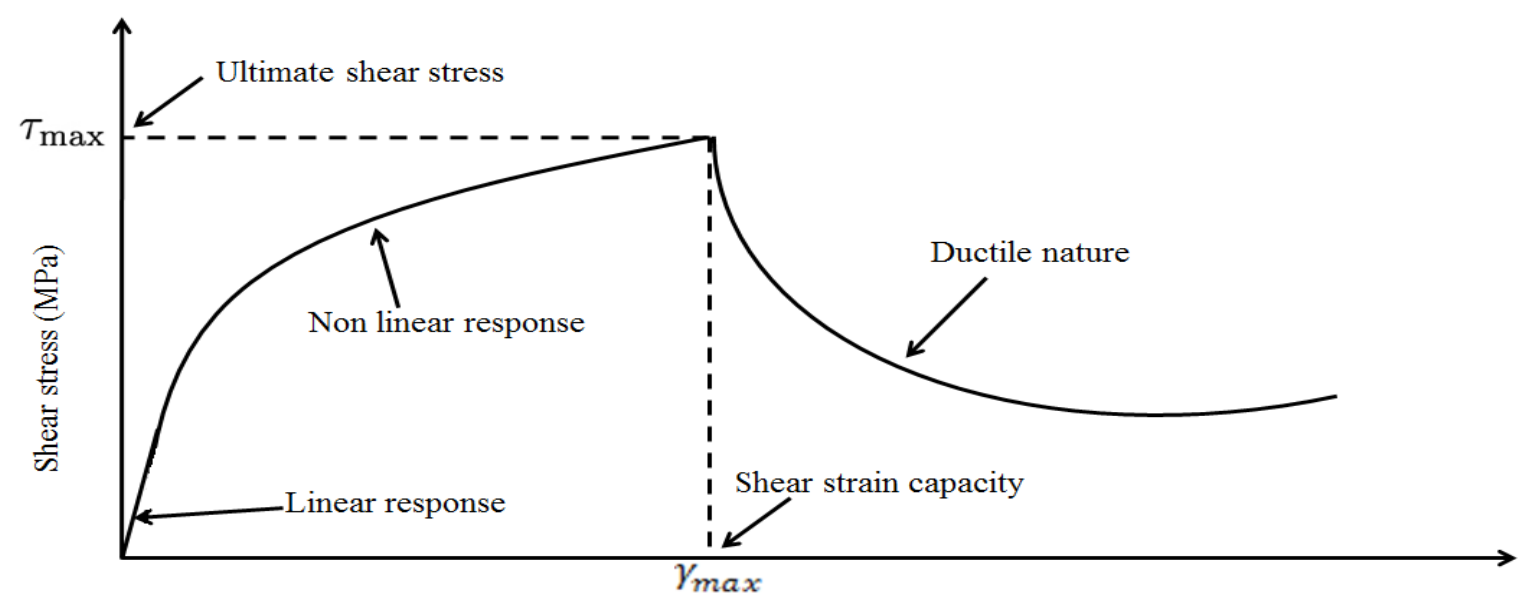

Shear strain

Fig. 12. Shear stress-strain curve for UHPFRC 
Flexural strength sometimes may be a more important feature than the compressive strength of UHPC. Types of aggregates, fibres and the casting methods are some of the important factors which significantly affects the flexural strength of UHPC. Fine aggregates like barite sand, quartz and nano materials (e.g. nano-silica) provides better flexural strength due to their stronger bond with hardened paste [124]. Content of nano-silica up to $2 \%$ improves the ITZ of the concrete matrix whereas it's over dosage (2\% $5 \%$ ) causes agglomeration. Hence, the flexural strength of UHPC increases only up to $2 \%$ vol. of nano-silica after which a significant decrease has been observed. The performance of fibres under the flexural loading not only depends upon the type of fibres, but also on the bridging capability, homogenous distribution and their orientation in the matrix. Even though the fibre has greater mechanical strength and bridging capability, their efficiency will decrease under loading if they are not homogeneously distributed and pertinently oriented. Due to this, many contradictory results have been obtained by different researches regarding contribution of fibres in improving the flexural properties of UHPC. Some results [102] have shown that the twisted fibres increase the flexural strength by $167 \%$ as compared to straight fibres. Whereas, some other results [135] shows that the best toughness and flexural strength was obtained for the beams incorporated with straight fibres as compared to twisted one. Yoo et al. [102] also stated that better flexural strength, fracture energy and toughness is obtained by using longer fibres due to their improved pull out performance. Addition of single or hybrid (medium \& long)fibres significantly enhances the toughness property up to $80 \%$ due to their cracking resistance characteristic [148]. It is noticeable that better flexural performance is obtained by using single twisted fibres (2\%) as compared to hybrid twisted and straight fibres [135]. Further, results have demonstrated that the standard curing is better than steam curing whereas the autoclave curing has shown the intermediate results [7]. The flexural strength is also influenced by the casting method as it will affects the orientation of fibres. An improved performance of UHPC under flexure will be obtained by increasing the speed of casting in layer casting method for uniaxial beams [135].

Having higher strength and improved durability as compared to ordinary concrete, UHPC provides much better earthquake and impact resistance. It is characterized with higher dissipation of energy under impact loadings and much better post loading performance. The important factors affecting the resistance capability of UHPC against impact loadings are specimen size, fibres (type, dosage, length, orientation) and mineral admixtures [149]. Optimum dosage of long length straight steel fibres is required for the significant enhancement of capacity to absorb energy and residual moment capacity along with remarkable increment in ultimate residual deflection capacity [150]. Moreover, the impact resistance, toughness and strain capacity increase with the decrease in specimen size and with parallel fibres alignment. Addition of fine mineral admixtures have always improved the performance of UHPC under the seismic and blast loadings. According to Wu et al. [151], the impact resistance capacity of UHPC get improved on incorporation of SCMs and fibres in it due to enhancement in its microstructure, ductility and toughness properties. Moreover in 2014, Astarlioglu and Krauthammer [152] stated that UHPC columns had shown $30 \%$ lesser displacement in comparison to conventional concrete columns under blast loadings. Hence, UHPC have a promising scope in field of military seismic zoned structures where high resistance to explosion and seismic loading is required.

\section{DURABILITY PROPERTIES}

Water absorption of a concrete represents its long-term durability performance. The durability of a concrete increases with the decrease in its water absorption capacity. The information regarding concrete's porosity and the volume of permeable pores along with their interconnectivity can easily be obtained from the water absorption capacity of that concrete [176]. A limited connectivity of pores and the reduction in porosity will significantly reduce the water absorption capacity [78]. With the addition of mineral admixtures in UHPC, its microstructure becomes highly homogenous and the ITZ thickness get reduced significantly. This decreases the water absorption capacity of UHPC by partially blocking the transportation channel of water [177]. Basically, the effect of mineral admixture's addition is more on final water absorption capacity (72 h) as compared to its initial absorption capacity (30 min) [176]. Sabet et al. [176] further added that the fly ash, natural zeolite or silica fume have a tendency of effectively reducing the water absorption rate of UHPC. However, silica fume provides the most effective results as the final water absorption decreased by $38.7 \%$ and $43 \%$ on its $10 \%$ and $20 \%$ incorporation respectively [176].

The durability of concrete also depends upon the resistance of concrete to the penetration of chloride ions. Higher chloride resistance capability of concrete results to the higher ductility. Basically, the important factors on which the chloride penetration depends are water-binder ratio, curing regime, type of exposure and its duration [178]. Addition of cementitious materials and provision of thermal treatment effectively enhances the resistance capability of concrete against chloride penetration. Results [179] shows that thermally treated UHPC provide very lower coefficient of chloride diffusion $\left(2 \times 10^{-14} \mathrm{~m}^{2} / \mathrm{s}\right)$ as compared to high performance concrete (HPC $-6 \times 10^{-13}$ $\left.\mathrm{m}^{2} / \mathrm{s}\right)$ and ordinary concrete $\left(1 \times 10^{-12} \mathrm{~m}^{2} / \mathrm{s}\right)$. The electric charge passed in terms of coulomb is another way to represent the chloride penetration in a specimen [180]. Generally, the chloride penetration is assumed to be negligible in materials having the coulomb value lower than 100.Schmidt et al. [181] shows that thermal treatment of UHPC provide a coulomb value of 22 which is very less as compared to 1736 coulombs in ordinary concrete.

Ultra high performance concrete (UHPC) are highly resistant to freezing-thawing actions. The highly enhanced homogenous microstructure, lower permeability and the reduced porosity are the main factors which provide such a great resistance [145]. Normally, it can sustain a freezing- 
thawing cycles of 400 to 500 and wetting-drying cycles of 4500 without any degradation [182]. Furthermore, Acker and Behloul [65] also showed that freeze-thaw cycle of 300 have no degradation effect on the microstructure of UHPC.
Concrete deterioration due to freeze-thaw is expressed in terms of Relative Dynamic Modulus (RDM) given in ASTM C 666 and can be calculated from the equation given in Table 12 [183].

Table 12: Equation for calculating relative dynamic modulus[183]

\begin{tabular}{ll}
\hline \hline Parameter & Mathematical equation \\
\hline \hline Relative Dynamic Modulus (RDM) & $R D M \%=\frac{f_{n}^{2}}{f^{2}} \times 100$ \\
\hline \hline$f_{n}=$ resonant frequency after " $\mathrm{n}$ " no. of cycles; $\mathrm{n}=$ no. of freeze-thaw cycles; \\
$f=$ initial resonant frequency @ $\mathrm{n}=$ zero;
\end{tabular}

After a significant number of freeze-thaw cycles, internal micro-cracks get generated and the concrete deterioration starts along with their further propagation. The RDM value starts reducing with the deterioration of concrete due to decrease in the resonant frequency [184]. For UHPC, Lee et al. [185] obtained a retained RDM value of $90 \%$ whereas Bonneau et al. [186] get the $0 \%$ decrease in the RDM value, after providing 1000 and 300 freeze-thaw cycles respectively. Addition of some mineral admixtures also enhances the freeze-thaw resistance of UHPC. Only $10 \%$ of class $\mathrm{C}$ fly ash and silica fume significantly increases the resistance capability of UHPC [187]. All these results demonstrate that UHPC have a very sound performance under freezing and thawing.

Ultra high performance concrete (UHPC) have highly dense microstructure and very low water-binder ratio. Due to this, it is highly vulnerable to fire attacks. During fire, the concrete gets exposed to high temperature of $1000^{\circ} \mathrm{C}$ to $1200^{\circ} \mathrm{C}$ which produces some physical and chemical metamorphosis in the concrete matrix as shown in (Table 13). These metamorphoses cause the disintegration of concrete structures and mainly depends upon the rate of heating, ultimate temperature and the former fire subjection [188]. There is a development of internal pore pressure due to evaporation of free water $\left(100^{\circ} \mathrm{C}\right)$ and the loss of $\mathrm{CSH}$ bounded water $\left(200^{\circ} \mathrm{C}-250^{\circ} \mathrm{C}\right)$. Spalling i.e. the explosion of concrete take place when this internal pressure exceeds the bearing capacity of concretes.

$Y e$ et al. [189] find that the maximum cracks in UHPC were generated at $300^{\circ} \mathrm{C}$ and the complete explosion take place at $400^{\circ} \mathrm{C}$. Addition of fibres will enhance the fire resistance capability of UHPC as after their burning and melting, capillary pores get developed along with the interlinking of cement matrix and aggregate's transition zone [190]. This will increase the permeability and decrease the steam pressure. Polypropylene (PP) fibres have been found the best reinforcement for increasing resistance of UHPC against fire as compared to others like steel. Introduction of PP fibre with incorporation density of $2 \mathrm{Kg} / \mathrm{m}^{3}$ showed negligible changes in UHPC for temperature up to $300^{\circ} \mathrm{C}$ and little deformation at $400^{\circ} \mathrm{C}$ [189].

Table 13: Physical and Chemical metamorphosis under temperature change

\begin{tabular}{|c|c|c|}
\hline & Scale & Physical \& Chemical Metamorphosis \\
\hline i. & Microscopic scale & $\begin{array}{l}\text { Drying - evaporation of free water. } \\
>\quad \text { Dehydration - loss of CSH bounded water. } \\
\quad \text { Pore pressure development. }\end{array}$ \\
\hline ii. & Mesoscopic scale & $\begin{array}{l}\begin{array}{l}\text { Contradictory strain between shrinkage of binder paste and expansion } \\
\text { of aggregates. }\end{array} \\
\end{array}$ \\
\hline iii. & Macroscopic level & $\begin{array}{l}>\text { Thermal augmentation. } \\
>\quad \text { Formation of cracks. } \\
>\quad \text { Spalling stimulation. }\end{array}$ \\
\hline
\end{tabular}

\section{CONCLUSIONS}

Based on the comprehensive review and discussions made in this paper, following conclusions are emphasized in the end:

$>$ Microstructure improvement, homogeneity enhancement, porosity reduction, excellent hydration and toughness betterment are the basic requirements for producing UHPC.For this, the basic requirements of UHPC mix are very high binder content, low water-binder ratio, high quantity of superplasticizers, good quality of fibres and excellent mix design along with proper curing.

> Fine mineral admixtures like silica fume, fly ash, metakaolin, nano-materials etc. are very efficient in enhancing the overall performance of UHPC.
The best aggregates which should be used for UHPC are characterized by high mechanical strength (hard, durable etc.), well graded size distribution and free from any harmful contaminants (clay, silt, chemicals etc.) so that it may not affect the strength, density and porousness of the concrete matrix.The fibres addition provides a ductile behaviour as well as a better resistance against the crack generation and propagation.

$>$ Modified Andreason and Andersen model is one of the best approaches for UHPC mix design. It acts as a target function and adjustment of every single material in the mix will be carried out until the target mix and composed mix curve provides an optimum fit. In the design mix, incorporation 
of sound quantity of superplasticizers, nano mineral admixtures and the air entraining agents will improve the workability of UHPC without compromising with its strength and long-term performance.

$>$ Compressive strength can be enhanced significantly on incorporation of mineral admixtures in the concrete mix. Fibre's addition has a very negligible effect on compressive strength as it is mainly responsible for enhancing the tensile and flexural strength of UHPC. Optimum dosage of long length straight steel fibres and fine mineral admixtures are required along with decreased specimen size and parallel fibre orientation for the significant enhancement of capacity to absorb energy and residual moment capacity along with remarkable increment in ultimate residual deflection capacity.

$>$ On increasing water to cement ratio, the dry shrinkage increases whereas autogenous shrinkage decreases. But, both types of shrinkage increase with the addition of high volume of superplasticizers in the concrete matrix. Provision of thermal treatment to the UHPC is one of the best methods to reduce the creep effectively. On the other hand, addition of fibres will enhance the fire resistance capability of UHPC due to the development of capillary pores on their burning and melting, which will increase the permeability and decrease the steam pressure.

$>$ The durability of UHPC increases with the decrease in the water absorption capacity, chloride penetration and increase in the freezing-thawing resistance. Incorporation of mineral admixtures, proper heat treatment and maintaining the watercement ratio can help to achieve highly enhanced homogenous microstructure, reduced porosity and lesser permeability. It will increase the durability of UHPC by checking the durability parameters.

Advanced capabilities in production and management, proper design guidelines, codes and standards, and industrial research to balance cost and benefits of UHPC are some of the basic needs to make it a commercialised construction material.

\section{REFERENCE}

[1] Yudenfreund M, Odler I, Brunauer S. Hardened Portland cement pastes of low porosity, I. "Materials and experimental methods". Cem Concr Res. 1972;2(3):313-330.

[2] Bache HH. Densified cement/ultra fine particle based materials. Second International Conference on Superplasticizers in Concrete; Ottawa, Canada; 1981.

[3] Birchall JD, Howard AJ, Kendall K. Flexural strength and porosity of cement. Nature. 1981;289:388-390.

[4] Richard P, Cheyrezy M. Composition of reactive powder concretes. Cem Concr Res. 1995;25(7):1501-1511.

[5] ACI Committee 239. Ultra high performance concrete. Toronto, Ontario, Canada: ACI Fall Convention; 2012

[6] Su Y, Wu C, Li J, et al. Development of novel ultra-high performance concrete: From material to structure, Constr Build Mater. 2017;135: 517-528.
[7] Yazici H, Yardimci MY, Aydin S, Karabulut AS. Mechanical properties of reactive powder concrete containing mineral admixtures under different curing regimes. Constr Build Mater. 2009;23(3):1223-1231.

[8] Shi C, Wu Z, Xiao J, et al. A review on ultra high performance concrete: Part I. Raw materials and mixture design. Constr Build Mater. 2015;101: 741-751

[9] Sorelli L, Constantinides G, Ulm FJ, Toutlemonde F. The nanomechanical signature of ultra high performance concrete by statistical nanoindentation techniques. Cem Concr Res. 2008; 38(12): $1447-1456$

[10] Rossi P. Ultra high performance fibre reinforced concrete (UHPFRC): a summary of current knowledge. Concr Intl 2008;30(2):31-34.

[11] Chan YW, Chu SH. Effect of silica fume on steel fibre bond characteristics in reactive powder concrete. Cem Concr Res. 2004;34(7):1167-1172. 38 O. Mishra and S. P. Singh

[12] Odler I, R€obler M. Investigations on the relationship between porosity, structure and strength of hydrated Portland cement pastes. II. Effect of pore structure and of degree of hydration Cem Concr Res. 1985;15(3): 401-410.

[13] R€obler M, Odler I. Investigations on the relationship between porosity, structure and strength of hydrated Portland cement pastes I. Effect of porosity. Cem Concr Res. 1985;15(2): 320330.

[14] Gołaszewski J, Szwabowski J. Influence of superplasticizers on rheological behaviour of fresh cement mortars. Cem Concr Res. 2004;34(2): 235-248.

[15] Yoshioka K, Tazawa E, Kawai K, Enohata T. Adsorption characteristics of superplasticizers on cement component minerals. Cem Concr Res. 2002; 32(10):1507-1513. [16] Wang $\mathrm{D}$, Shi $\mathrm{C}, \mathrm{Wu} \mathrm{Z}$, et al. A review on ultra high performance concrete: Part II. Hydration, microstructure and properties. Constr Build Mater. 2015; 96:368-377.

[17] Lai JZ. The studies of mechanical performances, durability, and micro mechanism of ecological reactive powder concrete [Ph.D. Thesis]. Southeast University; China; 2003.

[18] Yazici H, Yigiter H, Karabulut AS, Baradan B. Utilization of fly ash and ground granulated blast furnace slag as an alternative silica source in reactive powder concrete. Fuel 2008;87: 24012407.

[19] Zollo RF. Fibre-reinforced concrete: an overview after 30 years of development. Cem Concr Compos. 1997; 19(2):107-122.

[20] Sellevold EJ. Pozzolans, TKT 4215 Concrete Technology. Norway: Trondheim; 2009. [21] Coin Project Report-44. Ultra high performance fibre reinforced concrete (UHPFRC)-State of the Art. Oslo: SINTEF Building and Infrastructure; 2012.

[22] Talebinejad I, Bassam SA, Iranmanesh A, Shekarchizadeh M. Optimizing mix proportions of normal weight reactive powder concrete with strengths of 200-350 MPa. Proceedings of the International Symposium on Ultra High Performance Concrete; Kassel, Germany; 2004. p. 133-141.

[23] Wu Z, Shi C, Khayat KH. Influence of silica fume content on microstructure development and bond to steel fiber in ultra-high strength cement-based materials (UHSC). Cem Concr Compos. 2016;71:97-109.

[24] Malhotra VM, Mehta PK. High performance, high volume fly-ash concrete: Materials, mixture, proportioning, properties, construction practice and case histories. Ottawa: Supplementary Cementing Materials for Sustainable Development Inc.; 2002.

[25] Tafraoui A, Escadeillas G, Lebaili S, Vidal T. Metakaolin in the formulation of UHPC. Constr Build Mater. 2009; 23(2):669-674.

[26] Tuan NV, Ye G, Breugel KV, et al. The study of using rice husk ash to produce ultra high performance concrete. Constr Build Mater. 2011;25(4): 2030-2035.

[27] Malagavelli V, Rao PN. High performance cwith GGBS and ROBO sand. Int Jour Eng Sci Techol. 2012;2(10): 5107-5113.

[28] Sobolev K, Gutierrez MF. How nanotechnology can change the concrete world: Part 1. Am Ceram Soc Bull. 2005;84(10):14-17.

[29] Sanchez F., Sobolev K. Nanotechnology in concrete - a review. Constr Build Mater. 2010; 24(11):2060-2071.

[30] Ghafari E, Costa H, Julio ENBS. Optimization of UHPC by adding nanomaterials. Proceedings of Hipermat-Third International Symposium on UHPC and Nanotechnology for Construction Materials. Kassel University Press, Kassel, Germany; 2012. 
[31] Wu Z, Shi C, Khayat KH, Wan S. Effects of different nanomaterials on hardening and performance of ultrahigh strength concrete (UHSC). Cem Concr Compos. 2016;70:24-34. [32] Wu $\mathrm{Z}$, Khayat KH, Shi C. Effect of nano-SiO2 particles and curing time on development of fiber-matrix bond properties and microstructure of ultrahigh strength concrete. Cem Concr Res. 2017;95:247-256

[33] Wu Z, Shi C, Khayat KH. Multi-scale investigation of microstructure, fiber Journal of Sustainable Cement-Based Materials 39 pullout behavior, and mechanical properties of ultrahigh performance concrete with nano-CaCO3 particles. Cem Concr Compos. 2018;86:255-265.

[34] Yang SL, Millard SG, Soutsos MN, et al. Influence of aggregate and curing regime on the mechanical properties of ultra-high performance fibre reinforced concrete (UHPFRC). Constr Build Mater. 2009;23(6):2291-2298.

[35] Zhao SJ, Fan JJ, Sun W. Utilization of iron ore tailings as fine aggregate in ultra high performance concrete. Constr Build Mater. 2014;50:540-548

[36] Collepardi S, Coppola L, Troli R, Collepardi M. Mechanical properties of modified reactive powder concrete. ACI Spec Publ. 1997;173:1-22. [37] Shi Q. Study on compressive strength of gravel reactive powder concrete [Ph.D. thesis]. China: Beijing Jiaotong University; 2010

[38] Camacho E, Lopez JA, Serna P. Definition of three levels of performance for UHPFRC-VHPFRC with available materials. Proceedings of Hipermat-3rd International Symposium on UHPC and Nanotechnology for Construction Materials. Kassel University Press, Kassel, Germany; 2012.

[39] Deeb R, Ghanbari A, Karihaloo BL. Development of selfcompacting high and ultra high performance concretes with and without steel fibres. Cem Concr Compos. 2012;34(2):185-190.

[40] Yanga IH, Joh C, Kimb BS. Structural behavior of ultra high performance concrete beams subjected to bending. Eng Struct. 2010;32:3478-3487. [41] Kang ST, Lee Y, Park YD, Kim JK. Tensile fracture properties of an ultra high performance fiber reinforced concrete (UHPFRC) with steel fiber. Compost Struct. 2010;92:61-71.

[42] Kang ST, Kim JK. The relation between fiber orientation and tensile behavior in an Ultra High Performance Fiber Reinforced Cementitious Composites (UHPFRCC). Cem Concr Res. 2011;41:1001-1014

[43] Hassan AMT, Jones SW, Mahmud GH. Experimental test methods to determine the uniaxial tensile and compressive behaviour of ultra high performance fibre reinforced concrete (UHPFRC). Constr Build Mater. 2012; 37:874-882.

[44] Zhao S, Sun W. Nano-mechanical behavior of a green ultra-high performance concrete. Constr Build Mater. 2014;63:150-160.

[45] Yoo DY, Kang ST, Lee JH, Yoon YS. Effect of shrinkage reducing admixture on tensile and flexural behaviors of UHPFRC considering fiber distribution characteristics. Cem Concr Res. 2013; 54:180-190.

[46] Yu R, Spiesz P, Brouwers HJH. Effect of nano-silica on the hydration and microstructure development of UltraHigh Performance Concrete (UHPC) with a low binder amount. Constr Build Mater. 2014:65:140-150.

[47] Yoo DY, Shin HO, Yang JM, Yoon YS. Material and bond properties of ultra high performance fiber reinforced concrete with micro steel fibers. Compos Part B. 2014;58:122-133.

[48] Abbas S, Soliman AM, Nehdi ML. Exploring mechanical and durability properties of ultra-high performance concrete incorporating various steel fiber lengths and dosages. Constr Build Mater. 2015;75:429-441.

[49] Gesoglu M, G€uneyisi E, Nahhab AH, Yazıcı H. Properties of ultra-high performance fiber reinforced cementitious composites made with gypsum-contaminated aggregates and cured at normal and elevated temperatures. Constr Build Mater. 2015;93:427-438.

[50] Li W, Huang Z, Cao F, et al. Effects of nano-silica and nanolimestone on flowability and mechanical properties of ultra-highperformance concrete matrix. Constr Build Mater. 2015;95: 366374

[51] Yoo DY, Banthia N, Kim SW, Yoon YS. Response of ultra-highperformance fiber-reinforced concrete beams with continuous steel reinforcement subjected to low-velocity impact loading. Compos Struct. 2015;126: 233-245.
[52] Yoo DY, Kang ST, Yoon YS. Enhancing the flexural performance of ultra-high-performance concrete using long steel fibers. Compos Struct. 2016; 147:220-230.

[53] Wu Z, Shi C, He W, Wu L. Effects of steel fiber content and shape on mechanical properties of ultra high performance concrete Constr Build Mater. 2016;103:8-14. 40 O. Mishra and S. P. Singh

[54] Yoo DY, Banthia N, Kang ST, Yoon YS. Effect of fiber orientation on the rate-dependent flexural behaviour of ultra-highperformance fiber-reinforced concrete. Compos Struct. 2016;157: $62-70$.

[55] Xu S, Wuc C, Liu Z, et al. Experimental investigation of seismic behavior of ultra-high performance steel fiber reinforced concrete columns. Eng Struct. 2017;152:129-148.

[56] Xu Y, Liu J, Liu J, et al. Experimental studies and modeling of creep of UHPC. Constr Build Mater. 2018;175: 643-652.

[57] Liua J, Wua C, Sua Y, et al. Experimental and numerical studies of ultra-high performance concrete targets against high-velocity projectile impacts. Eng Struct. 2018:173: 166-179.

[58] Casagrande CA, Cavalaro SHP, Repette WL. Ultra-high performance fibre-reinforced cementitious composite with steel microfibres functionalized with silane. Constr Build Mater 2018;178:495-506.

[59] Meng W, Khayat K. Effect of graphite nanoplatelets and carbon nanofibers on rheology, hydration, shrinkage, mechanical properties, and microstructure of UHPC. Cem Concr Res. 2018;105: 64-71.

[60] Ren GM, Wu H, Fang Q, Liu JZ. Effects of steel fiber content and type on dynamic compressive mechanical properties of UHPCC. Constr Build Mater. 2018;164:29-43.

[61] Shen P, Lu L, He Y, et al. Experimental investigation on the autogenous shrinkage of steam cured ultra-high performance concrete. Constr Build Mater. 2018;162: 512-522.

[62] Hirschi T, Wombacher F. Influence of different superplasticizer on UHPC. Proceedings of the Second International Symposium on Ultra High Performance Concrete; Kassel University Press, Kassel, Germany; 2008. p. 77-84.

[63] Schr€ofl C, Gruber M, Plank J. Preferential adsorption of polycarboxylate superplasticizers on cement and silica fume in ultra high performance concrete (UHPC). Cem Concr Res. 2012;42(11):1401-1408.

[64] Ma X, Liu J, Wu Z, Shi C. Effects of SAP on the properties and pore structure of high performance cement-based materials. Constr Build Mater. 2017; 131:476-484

[65] Acker P, Behloul M. DuctalVR Technology: A large spectrum of properties, a wide range of applications. Proceedings of the International Symposium on Ultra High Performance Concrete; Kassel, Germany; 2004. p. 11-23.

[66] Andreasen AHM, Andersen J. Uber $€$ die Beziehungen zwischen Kornabstufungen und Zwischenraum in Produkten aus losen K€ornern (mit einigen Experimenten). Kolloid Z. 1930;50:217228.

[67] Larrard FD, Sedran T. Optimization of ultra-high-performance concrete by the use of a packing model. Cem Concr Res. 1994;24:997-1009.

[68] Larrard FD, Sedran T. Mixture-proportioning of high-performance concrete. Cem Concr Res. 2002;32:1699-1704.

[69] Funk JE, Dinger DR. Predictive process control of crowded particulate suspensions, applied to ceramic manufacturing. Boston, USA: Kluwer Academic Publishers; 1994.

[70] H€usken G, Brouwers HJH. A new mix design concept for eachmoist concrete: a theoretical and experimental study. Cem Concr Res. 2008;38: 1249-1259

[71] Yu R, Spiesz P, Brouwers HJH. Mix design and properties assessment of Ultra-High Performance Fibre Reinforced Concrete (UHPFRC). Cem Concr Res. 2014;56:29-39.

[72] H€usken G. A multifunctional design approach for sustainable concrete with application to concrete mass products [ $\mathrm{PhD}$ thesis]. Eindhoven, the Netherlands: Eindhoven University of Technology; 2010

[73] Wille K, Naaman AE, ParraMontesinos GJ. Ultra-high performance concrete with compressive strength exceeding 150 MPa (22 ksi): a simpler way. ACI Mater J. 2011; 108(1):46-54.

[74] Rossi P. Development of new cement composite materials fo construction. Proc Instit Mech Eng L J Mater Design Applicat. 2005;219(L1):67-74. 
[75] Shakhmenko G, Korjakins A, Kara P, et al. UHPC containing nanoparticles Journal of Sustainable Cement-Based Materials 41 synthesized by sol-gel method. Proceedings of the 3rd International Symposium on UHPC and Nanotechnology for High Performance Construction Material. Kassel, Germany; 2012. p. 79-85.

[76] Korpa A, Kowald T, Trettin R. Phase development in normal and ultra high performance cementitious systems by quantitative $\mathrm{X}$ ray analysis and thermo analytical methods. Cem Concr Res. 2009;39:69-76.

[77] Tuan NV, Ye G, Breugel K, Copuroglu O. Hydration and microstructure of ultra high performance concrete incorporating rice husk ash. Cem Concr Res. 2011;41:1104-1111.

[78] Shetty MS. Concrete technology - theory and practice. New Delhi, India: S. Chand and Company Ltd.; 2006.

[79] Juenger MCG, Siddique R. Recent advances in understanding the role of supplementary cementitious materials in concrete. Cem Concr Res. 2015;78: 71-80.

[80] Nadeem A, Memon SA, Lo TY. Mechanical performance, durability, qualitative and quantitative analysis of microstructure of fly ash and metakaolin mortar at elevated temperatures. Constr Build Mater. 2013;38:338-347.

[81] Madandoust R, Ranjbar MM, Moghadam HA, Mousavi SY. Mechanical properties and durability assessment of rice husk ash concrete. Biosyst Eng. 2011;110:144-152.

[82] Yu R, Spiesz P, Brouwers HJH. Development of an eco-friendly ultrahigh performance concrete (UHPC) with efficient cement and mineral admixtures uses. Cem Concr Compos. 2015;55:383-394.

[83] Kang SH, Hong SG, Moon J. The use of rice husk ash as reactive filler in ultra-high performance concrete. Cem Concr Res. 2018;

[84] Mehta KP, Monteiro PJM. Concrete structure, properties, and materials. 2nd ed. New Jersey: Prentics Hall; 1993. [85] Collepardi S, Coppola L, Troli R, Collepardi M. Mechanical properties of modified reactive powder concrete. ACI Spec Pub. 1997;173:1-22.

[86] Ma J, Dehn F, Tue NV, et al. Comparative investigations on ultrahigh performance concrete with and without coarse aggregates. Proceedings of International Symposium on UltraHigh Performance Concrete; Kassel, Germany; 2004. p. 205-212.

[87] Wong HC, Kwan AKH. Packing density: a key concept for mix design of high performance concrete. Proceedings of the Material Science and Technology in Engineering Conference; HKIE Materials Division, Hong Kong; 2005. p. 1-15.

[88] Mehta PK, Aïtcin PC. Microstructural basis of selection of materials and mix proportions for high-strength concrete. ACI Spec Publicat. 1990;121:265-286.

[89] Obla KH, Hill RL, Thomas MDA, et al. Properties of concrete containing ultra-fine fly ash. ACI Mater J. 2003; 100(5):426-433.

[90] Wille K, Kim DJ, Naaman AE. Strainhardening UHP-FRC with low fibre contents. Mater Struct. 2011;44(3): 583-598.

[91] Yoo DY, Yoon YS. Structural performance of ultra-highperformance concrete beams with different steel fibres. Eng Struct. 2015;102:409-423.

[92] $\mathrm{Wu} \mathrm{Z}$, Khayat $\mathrm{KH}$, Shi C. How do fiber shape and matrix composition affect fiber pullout behavior and flexural properties of UHPC? Cem Concr Compos. 2018;90:193-201

[93] Yoo DY, Banthia N. Mechanical properties of ultra-highperformance fibrereinforced concrete: a review. Cem Concr Compos. 2016;73:267-280. [94] Wu Z, Shi C, He W, Wang D. Static and dynamic compressive properties of ultra-high performance concrete (UHPC) with hybrid steel fiber reinforcements. Cem Concr Compos. 2017;79:148-157.

[95] Wu Z, Shi C, He W, Wang D. Uniaxial compression behavior of ultra-high performance concrete with hybrid steel fiber. ASCE J Mater Civil Eng. 2016;28(12):1-7.

[96] Yoo DY, Lee JH, Yoon YS. Effect of fibre content on mechanical and fracture properties of ultra high performance fibre reinforced cementitious composites. Comp Struct 2013;106: 742-753.

[97] Boulekbache B, Hamrat M, Chemrouk M, Amziane S. Flowability of fibre reinforced concrete and its effect on the mechanical properties of the material. Constr Build Mater. 2010;24(9): 16641671. 42 O. Mishra and S. P. Singh
[98] Ferrara L, Ozyurt N, Di Prisco M. High mechanical performance of fibre reinforced cementitious composites: the role of "castingflow induced" fibre orientation. Mater Struct. 2011; 44(1):109128

[99] Kwon SH, Kang ST, Lee BY, Kim JK. The variation of flowdependent tensile behavior in radial flow dominant placing of Ultra High Performance Fibre Reinforced Cementitious Composites (UHPFRCC). Constr Build Mater. 2012;33:109-121. [100] An MZ, Zhang LJ, Yi QX. Size effect on compressive strength of reactive powder concrete. J Chin Univ Min Technol. 2008;18(2):279-282.

[101] Kazemi S, Lubell AS. Influence of specimen size and fibre content on mechanical properties of ultra-highperformance fibrereinforced concrete. ACI Mater J. 2012;109(6):675-684.

[102] Yoo DY, Banthia N, Kang ST, Yoon YS. Size effect in ultrahigh-performance concrete beams. Eng Frac Mech. 2016;157:86106. [103] Aïtcin BDPC. The hidden meaning of the water-tocement ratio. Concr Intern. 2008;30(5):51-54.

[104] Aitcin PC. 1 - The importance of the water-cement and waterbinder ratios. Sci Technol Concr Admixt. Woodhead Publishing Sawston, UK. 2016;3-13.

[105] Zhang YS, Sun W, Liu SF, et al. Preparation of C200 green reactive powder concrete and its static-dynamic behaviors. Cem Concr Compos. 2008; 30(9):831-838.

[106] Masse S, Zanni H, Lecourtier J, et al. 29Si solid state NMR study of tricalcium silicate and cement hydration at high temperature. Cem Concr Res. 1993;23(5):1169-1177.

[107] Yazici H. The effect of curing conditions on compressive strength of ultra high strength concrete with high volume mineral admixtures. Build Environ. 2007;42(5):2083-2089.

[108] Koh KT, Park JJ, Ryu GS, Kang ST. Effect of the compressive strength of ultra-high strength steel fibre reinforced cementitious composites on curing method. J Korean Soc Civil Eng. 2007;27(3A):427-432

[109] Wu Z, Shi C, He W. Comparative study on flexural properties of ultrahigh performance concrete with supplementary cementitious materials under different curing regimes. Constr Build Mater 2017;136:307-313.

[110] AFGC and SETRA. Ultra high performance fibre-reinforced concretes - interim recommendations. Report. Association Francaise de Genie Civil. 2002. [111] Banthia N, Chokri K, Ohama Y, Mindess S. Fibre-reinforced cement based composites under tensile impact. Adv Cem Based Mater. 1994;1(3): 131-141.

[112] Rong Z, Sun W, Zhang Y. Dynamic compression behavior of ultra-high performance cement based composites. Int J Impact Eng. 2010;37(5):515-520.

[113] Wille K, El-Tawil S, Naaman AE. Strain rate dependent tensile behavior of ultra-high performance fibre reinforced concrete. Proceedings of High Performance Fibre Reinforced Cement Composition 6; Netherlands; 2012. p. 381-387.

[114] Tran NT, Tran TK, Kim DJ. High rate response of ultra-highperformance fibre-reinforced concretes under direct tension. Cem Concr Res. 2015;69: 72-87.

[115] Fujikake K, Senga T, Ueda N, et al. Effects of strain rate on tensile behavior of reactive powder concrete. $\mathrm{J}$ Adv Concr Tech. 2006;4(1):79-84.

[116] Bindiganavile V, Banthia N, Aarup B. Impact response of ultrahigh-strength fibre-reinforced cement composite. ACI Mater J. 2002;99(6):543-548.

[117] Park SH, Kim DJ, Ryu GS, Koh KT. Tensile behavior of Ultra High Performance Hybrid Fibre Reinforced Concrete. Cem Concr Compos. 2012; 34:172-184. [118] Maca P, Sovjak R, Konvalinka P. Mix design of UHPFRC and its response to projectile impact. Intern . Impact Eng. 2014;63:158-163.

[119] Nguyen DL, Kim DJ, Ryu GS, Koh KT. Size effect on flexural behavior of ultra-high-performance hybrid fiberreinforced concrete. Compos Part B 2013;45:1104-1116.

[120] Yu R, Spiesz P, Brouwers HJH. Static properties and impact resistance of a green Ultra-High Performance Hybrid Fibre Reinforced Concrete (UHPHFRC): experiments and modelling. Constr Build Mater. 2014;68: 158-171. Journal of Sustainable Cement-Based Materials 43 [121] Ambily PS, Umarani C, Ravisankar K, et al. Studies on ultra high performance concrete incorporating copper slag as fine aggregate. Constr Build Mater. 2015;77:233-240. [122] Hussein L, Amleh L. Structural behavio 
of ultra high performance fibre reinforced concrete-normal strength concrete or high strength concrete composite members. Const Build Mater. 2015;93:1105-1116.

[123] Jankovic K, Stankovic S, Bojovic D, et al. The influence of nanosilica and barite aggregate on properties of ultra high performance concrete. Const Build Mater. 2016;126:147-156.

[124] Kang S, Choi J, Koh K, et al. Hybrid effects of steel fibre and microfibre on the tensile behaviour of ultra-high performance concrete. Compos Struct. 2016;145:37-42.

[125] Meng W, Khayat KH. Mechanical properties of ultra-highperformance concrete enhanced with graphite nanoplatelets and carbon nanofibres. Compos Part B 2016;107:113-122.

[126] Pyo S, El-Tawil S, Naaman AE. Direct tensile behavior of ultra high performance fiber reinforced concrete (UHPFRC) at high strain rates. Cem Concr Res. 2016;88:144-156.

[127] $\mathrm{Xu} \mathrm{J}$, Wua $\mathrm{C}$, Xiang $\mathrm{H}$, et al. Behaviour of ultra high performance fibre reinforced concrete columns subjected to blast loading. Eng Struct. 2016;118:97-107.

[128] Vaitkevic

ius V, Serelis E,

Vaic

iukyniene D, et al. Advanced mechanical properties and frost damage resistance of ultra-high performance fibre reinforced concrete. Constr Build Mater. 2016;126:26-31.

[129] Yu R, Spiesz P, Brouwers HJH. Energy absorption capacity of a sustainable Ultra-High Performance Fibre Reinforced Concrete (UHPFRC) in quasi-static mode and under high velocity projectile impact. Cem Concr Compos. 2016;68:109-122.

[130] Alsalman A, Dang CN, Hale WM. Development of ultra high performance concrete with locally available materials. Constr Build Mater. 2017; 133:135-145.

[131] Ngo TT, Park JK, Pyo S, Kim DJ. Shear resistance of ultra-highperformance fibre-reinforced concrete. Constr Build Mater. 2017;151:246-257.

[132] Pyo S, Kim H. Fresh and hardened properties of ultra-high performance concrete incorporating coal bottom ash and slag powder. Constr Build Mater. 2017;131:459-466

[133] Yoo DY, Kim S, Park GJ, et al. Effect of fibre shape, aspect ratio, and volume fraction on flexural behavior of ultra-highperformance fibre-reinforced cement composites. Compos Struct. 2017; $174: 375-388$

[134] Yoo DY, Kim SW, Park JJ. Comparative flexural behavior of ultrahigh-performance concrete reinforced with hybrid straight steel fibers. Constr Build Mater. 2017;132:219-229.

[135] Yoo DY, Kim MJ, Kim SW, Park JJ. Development of cost effective ultrahigh-performance fiber-reinforced concrete using single and hybrid steel fibers. Constr Build Mater. 2017;150: 383-394.

[136] Kim S, Kim MJ, Yoon H, Yoo DY. Effect of cryogenic temperature on the flexural and cracking behaviors of ultra-highperformance fiber-reinforced concrete. Cryogenics. 2018;93:7585 .

[137] Kim MJ, Yoo DY, Kim S, et al. Effects of fiber geometry and cryogenic condition on mechanical properties of ultra-highperformance fiberreinforced concrete. Cem Concr Res. 2018;107:30-40.

[138] Li PP, Yu QL, Brouwers HJH. Effect of coarse basalt aggregates on the properties of Ultra-high Performance Concrete (UHPC). Constr Build Mater. 2018;170:649-659.

[139] Pourbaba M, Asefi E, Sadaghian H, Mirmiran A. Effect of age on the compressive strength of ultra-high-performance fiberreinforced concrete. Constr Build Mater. 2018;175:402-410.

[140] Ren GM, Wu H, Fang Q, Liu JZ. Effects of steel fiber content and type on static mechanical properties of UHPCC. Constr Build Mater. 2018; 163:826-839.

[141] Graybeal BA. Characterization of the behaviour of ultra-high performance concrete. Department of Civil and Environmental Engineering, University of Maryland: College Park, MD, USA; 2005. [142] Graybeal B. Material property characterization of ultrahigh performance concrete. In FHWA-HRT-06-103. Vol. 44 O. Mishra and S. P. Singh 176. USA: US Department of Transportation; 2006.

[143] Soliman NA, Tagnit-Hamou A. Development of ultra-highperformance concrete using glass powder - towards ecofriendly concrete. Constr Build Mater. 2016;125:600-612.
[144] Nguyen DL, Ryu GS, Koh KT, Kim DJ. Size and geometry dependent tensile behavior of ultra high performance fibre reinforced concrete. Compos Part B. 2014;58:279-292.

[145] Prabha SL, Dattatreya JK, Neelamegam M, Seshagirirao MV Study on stress-strain properties of reactive powder concrete under uniaxial compression. Int $\mathbf{J}$ Eng Sci Technol. 2010;2(11):6408-6416.

[146] Farnam Y, Mirdamadi A, Shekarchi M. Experimental investigation of impact behavior of high strength fibre reinforced concrete panels. Proceedings of the second International Symposium on UltraHigh Performance Concrete; Kassel, Germany; 2008. p. 751-758

[147] Yoo DY, Banthia N. Mechanical and structural behaviors of ultra-high-performance fibre-reinforced concrete subjected to impact and blast. Constr Build Mater. 2017;149:416-431.

[148] Wu Z, Shi C, Khayat KH, Xie L. Effect of SCM and nanoparticles on static and dynamic mechanical properties of UHPC. Constr Build Mater. 2018;182:118-125.

[149] Astarlioglu S, Krauthammer T. Response of normal-strength and ultrahigh-performance fibre-reinforced concrete columns to idealized blast loads. Eng Struct. 2014;61:1-12.

[150] Roux N, Andrade C, Sanjuan M. Experimental study of durability of reactive powder concretes. J Mater Civil Eng. 1996;8(1):1-6.

[151] Garas VY, Kurtis KE, Kahn LF. Creep of UHPC in tension and compression: effect of thermal treatment. Cem Concr Compos. 2012;34:493-502.

[152] Ye H, Feng N, Ling-hu Y, et al. Research on fire resistance of ultrahigh-performance concrete. Adv Mater Sci Eng. 2012;530948:7 p.

[153] Sabet FA, Libre NA, Shekarchi M. Mechanical and durability properties of self consolidating high performance concrete incorporating natural zeolite, silica fume and fly ash. Constr Build Mater. 2013;44:175-184.

[154] Du H, Du S, Liu X. Durability performances of concrete with nano-silica. Constr Build Mater. 2014;73:705-712. [155] Yoo DY, Min KH, Lee JH, Yoon YS. Shrinkage and cracking of restrained ultra-high-performance fiber-reinforced concrete slab at early age. Constr Build Mater. 2014;73:357-365.

[156] Yoo DY, Banthia N, Yoon YS. Effectiveness of shrinkagereducing admixture in reducing autogenous shrinkage stress of ultra-high-performance fiber-reinforced concrete. Cem Concr Compos. 2015;64:27-36

[157] Li Z. Drying shrinkage prediction of paste containing meta-kaolin andultrafine fly ash for developing ultra-high performance concrete. Mater Today Commun. 2016;6:74-80.

[158] Tafraoui A, Escadeillas G, Thierry V. Durability of the ultra high performances concrete containing metakaolin. Constr Build Mater. 2016;112: 980-987.

[159] Li W, Huang Z, Hu G, et al. Early-age shrinkage development of ultra-highperformance concrete under heat curing treatment. Constr Build Mater. 2017;131:767-774.

[160] Liang X, Wua C, Sua Y, et al. Development of ultra-high performance concrete with high fire resistance. Constr Build Mater. 2018;179: 400-412. [161] Liu JC, Tan KH. Fire resistance of ultra-high performance strain hardening cementitious composite: residual mechanical properties and spalling resistance. Cem Concr Compos. 2018; 89:62-75

[162] Valipour M, Khayat KH. Coupled effect of shrinkage-mitigating admixtures and saturated lightweight sand on shrinkage of UHPC for overlay applications. Constr Build Mater. 2018;184: 320-329.

[163] Yoo DY, Kim S, Kim MJ. Comparative shrinkage behavior of ultra-high-performance fiber reinforced concrete under ambient and heat curing conditions. Constr Build Mater. 2018;162:406419

[164] Wu L, Farzadnia N, Shi C, et al. Autogenous shrinkage of high performance concrete: a review. Construct Build Mater. 2017;149:62-75. Journal of Sustainable Cement-Based Materials 45 [165] Xie T, Fang C, Mohamad Ali MS, Visintin P. Characterizations of autogenous and drying shrinkage of ultrahigh performance concrete (UHPC): an experimental study. Cem Concr Compos. 2018;91:156-173.

[166] Tazawa E. Technical committee report on autogenous shrinkage. Proc. JCI. 1996; 18:29-38. 
[167] FIB. Structural concrete - textbook on behaviour, design and performance. Lausanne: Federation Internationale du Beton. Vol. 51. 2009. p. 95-149.

[168] Tam CM, Tam Vivian WY, Ng KM. Assessing drying shrinkage and water permeability of reactive powder concrete produced in Hong Kong. Constr Build Mater. 2012;26:79-89.

[169] Ghafari E, Ghahari SA, Costa H, et al. Effect of supplementary cementitious materials on autogenous shrinkage of ultra-high performance concrete. Constr Build Mater. 2016;127:43-48.

[170] Garas VY, Kahn LF, Kurtis KE. Short-term tensile creep and shrinkage of ultra-high performance concrete. Cem Concr Compos. 2009;31: 147-152.

[171] Switek-Rey A, Denarie E, Br€uhwiler E. Early age creep and relaxation of UHPFRC under low to high tensile stresses. Cem Concr Res. 2016;83: 57-69.

[172] Thomas M, Green B, O'Neal E, et al. Marine performance of UHPC at Treat Island. Proceedings of the 3rd International Symposium on UHPC and Nanotechnology for High Performance Construction Materials; Kassel, Germany; 2012. p. 365-370.

[173] ASTM C1202-10. Standard test method for electrical indication of concrete's ability to resist chloride ion penetration. West Conshohocken, PA: ASTM International; 2010.

[174] Schmidt M, Fehling E, Teichmann T, et al. Ultra-high performance concrete: perspective for the precast concrete industry. Concr Precasting Plant Tech. 2003;69(3):16-29.

[175] Vernet P. Ultra-durable concretes: structure at the micro- and nano-scale. Mater Res Soc. 2004;29(5):324-327.

[176] Alkaysi M, El-Tawil S, Liu Z, Hansen W. Effects of silica powder and cement type on long term durability of ultra high performance concrete (UHPC). Cem Concr Compos. 2016; 66:47-56.

[177] Graybeal B, Tanesi J. Durability of an ultrahigh-performance concrete. J Mater Civil Eng. 2007;19:848-854.

[178] Lee MG, Chiu CT, Wang YC. The study for bond strength and bond durability of reactive powder concrete. J ASTM Int. 2005;2(7):104-113.

[179] Bonneau O, Lachemi M, Dallaire E, et al. Mechanical properties and durability of two industrial reactive powder concretes. ACI Mater J 1997; 94(4):286-290.

[180] Halit Y. The effect of silica fume and high-volume class C fly ash on mechanical properties, chloride penetration and freeze-thaw resistance of selfcompacting concrete. Constr Build Mater. $2008 ; 22(4): 456-462$
[181] Buttignol TET, Sousa JLAO, Bittencourt TN. Ultra highperformance fibre-reinforced concrete (UHPFRC): a review of material properties and design procedures. Rev IBRACON Estrut Mater. 2017;10(4): 957-971

[182] Xiong MX, Liew JYR. Spalling behavior and residual resistance of fibre reinforced ultra-high performance concrete after exposure to high temperatures. Mater Constr. 2015;65:e071.

[183] Prem PR, Murthy AR. Acoustic emission and flexural behaviour of RC beams strengthened with UHPC overlay. Constr Build Mater. 2016;123: 481-492

[184] Khan MI, Al-Osta MA, Ahmad S, Rahman MK. Seismic behavior of beam-column joints strengthened with ultra-high performance fiber reinforced concrete. Compos Struct. 2018;200: 103-119.

[185] Ricker M, H€ausler F, Randl N. Punching strength of flat plates reinforced with UHPC and double headed studs. Eng Struct. 2017; $136: 345-354$

[186] Ghasemi S, Zohrevand P, Mirmiran A, et al. A super lightweight UHPC-HSS deck panel for movable bridges. Eng Struct. 2016;113:186-193.

[187] El-Hacha R, Abdelazeema H, Cariaga I. Effect of casting method and shear span-to-depth ratio on the behaviour of ultra-high performance concrete cross arms for high voltage transmission lines. Eng Struct. 2010;32:2210-2220. 46 O. Mishra and S. P. Singh

[188] Nehdi ML, Abbas S, Soliman AM. Exploratory study of ultrahigh performance fiber reinforced concrete tunnel lining segments with varying steel fiber lengths and dosages. Eng Struct. 2015;101:733-742.

[189] Ultra high performance concrete-pathway to commercialization. US Department of Homeland Security, USA; 2011.

[190] Viacava IR, Cea AA, Sensale GR. Self-compacting concrete of medium characteristic strength. Constr Build Mater. 2012:30:776-782 